\title{
RELEVANSI KURIKULUM 2013 DENGAN PEMELAJARAN PAI DALAM UPAYA PEMBENTUKAN KARAKTER PESERTA DIDIK
}

\author{
${ }^{1}$ Abdullah, K, ${ }^{2}$ Fahmiah Akilah \\ ${ }^{1}$ Institut Agama Islam Negeri (IAIN) Bone \\ e-mail: abdullahkatutu@yahoo.co.id \\ ${ }^{2}$ Institut Agama Islam Negeri (IAIN) Parepare \\ e-mail: fahmiahakilah@iainpare.ac.id
}

\begin{abstract}
ABSTRAK
Conceptually, the 2013 curriculum relied heavily on Scientific methods, which in its application were more popular with the term $5 \mathrm{M}$ : Mengamati (observing),Menanya(asking), Mengumpul (gathering), Menalar (reasoning) and Mengkomunikasikan (communicating), and applied through scientific methods and approaches, such as: Contextual Teaching Learning, Enquiry, Problem Solving, Communicative, Cooperative and so on.And always starting and guided by the core curriculum, which is known by the four Main Competences (KompetensiInti/KI), namely: KI. 1: Spiritual Attitude KI.2: Social Attitude, KI. 3: Knowledge, and KI.4: Skills. The cultivation of character is integrated with the learning of Islamic Religious Education, so that the implementation is in line and agreed in shaping the mental attitude, social attitude, knowledge and skills.This means that humans who will be formed are people mentality or morality, intellectual andskills, or who will be formed is the heart (affective aspects), mind (cognitive aspects) and hands or feet (psycho-psychological aspects). In order for the students to have good moralsand avoid being chipped (mazmumah morals).The building up of the character values refers to the 2013 curriculum established by Ministry of National Education No. 68 of 2013 for Junior High School (SMP / MTs), namely: Faith, honesty, discipline, responsibility, care, (tolerance, mutual cooperation), polite, confidence in interacting effectively with the social and natural environment in the social term. The character has been instilled by Islamic Education (PAI) teachers who are quite professional, so that the results are quite intense, high, positive and entrenched, because the aim is the same, namely: forming commendable morals and avoiding despicable morals.
\end{abstract}

Keywords: Character, Curriculum, Learning

\section{METODE}

Adapun jenis penelitiaannya adalah deskriptif kualitatif, lalu dipecahkan secara pedagogik dengan menggunakan data primer dan sekunder. Pengumpulan data melalui field dan library research dengan teknik observasi, interview dan dukumenter, dengan menggunakan pedoman observasi, panduan interview serta pencatatan dokumenter, disertai indikator penelitian. Kemudian dilakukan penngolahan dan analisis data secara deskriptif dengan mengikuti langkah reduksi data, display data hingga penarikan kesmpulan. Setelah itu dilakukan pengujian keabsahan data dengan trianguasi sumber, metode dan waktu. Yang mau dipahami adalah konsepsi kurikulum 2013 dalam menanamkan nilai-nilai karakter terhadap peserta didik di tingkat MTs, dan impelementasinya dalam pembelajaran PAI dalam membentuk karakter peserta didik di MTsN Watampone. Karena isu pembelajarannya berbasis karakter, sehingga orang tua penuh optimisme dalam memasukkan 
anaknya di MTsN Watampone, dengan semangat bahwa karakter yang telah dimulai dan telah ditanamkan dalam rumah tangga dapat dilanjutkan dan dimantapkan di di madrasah tersebut.

\section{PEMBAHASAN}

Kurikulum merupakan salah satu komponen yang memiliki peran penting dalam sistem pendidikan, sebab dalam kurikulum bukan hanya dirumuskan tentang tujuan yang harus dicapai sehingga memperjelas arah pendidikan, akan tetapi juga memberikan pemahaman tentang pengalaman belajar yang harus dimiliki setiap peserta didik, demikian juga metode yang dipakai mengajar dan menilai oleh guru.

Kurikulum dan pembelajaran merupakan dua hal yang tidak dapat dipisahkan, karena kurikulum sebagai suatu rencana, tidak akan bermakna, manakala tidak diimpelementasikan dalam bentuk pembelajaran. Demikian juga sebaliknya, tanpa kurikulum yang jelas sebagai acuan, maka pembelajaran tidak akan berlangsung secara efektif. ${ }^{1}$

Kurikulum selalu berubah dari suatu periode ke periode berikutnya mengikuti dinamika sebagai tuntutan dalam meraih kualitas dan bergerak secara terus-menerus tanpa ujung. Perubahan kurikulum dari Kurikulum Tingkat Satuan Pendidikan (KTSP) ke konsep kurikulum 2013 yang lebih menekankan strategi dan model pembelajaran yang scientific.

Demikian juga pembelajaran Pendidikan Agama Islam (PAI) masih terdapat berbagai kekurangan, seperti: Metode pembelajaran agama kurang mendapat penggarapan. Islam diajarkan lebih pada hafalan, PAI lebih ditekankan pada hubungan formalitas antara hamba dengan Tuhannya. Penalaran dan argumentasi berpikir untuk masalah-masalah keagamaan dan penghayatan terhdap nilai-nilai agama serta orientasi pada kenyataan hidup sehari-hari kurang mendapat perhatian. Ukuran keberhasilan masih verbalistik/formalitas. Belum mampu menjadi landasan kemajuan dan kesuksesan untuk mata pelajaran lain, dan belum mampu menjadi pondasi pendidikan karakter dalam kehidupan sehari-hari. Banyak pihak yang menilai begitu lemahnya karakter bangsa, yang merupakan masalah nasional. Hal itu terjadi karena pendidikan mengalami disorientasi.

Untuk merubah kondisi seperti itu, maka pendidikan karakter mutlak diperlukan demi kelangsungan hidup bangsa, sehingga dalam mendidik bukan hanya aspek kecerdasan otak yang didambakan tetapi juga kecerdasan moral. Potensi akademik harus diimbangi dengan perilaku yang baik.

Penerapan kurikulum 2013 yang menekankan metode pembelajaran yang berbasis scientific dalam upaya pembentukan karakter, maka pembelajaran PAI akan terbantu dalam mengatasi segala

${ }^{1}$ Lihat Saylor Alexander \& Lewis, Curriculum Planning For Better Teaching and Learning, HoltRinehart and Winston, 1981, h. 10 dikutip oleh Wina Sanjaya, Kurikulum dan Pembelajaran, Jakarta: Kencana, 2008, h. vii. 
kelemahannya atau kekurangannya, karena pelan-pelan metode tradisional atau konvensional seperti ceramah dan dikte tergantikan metode scientific, seperti metode enqueri dan metode contekstual teaching learning, sehingga pembelajaran PAI semakin aktual dan handal dalam menamakan nilai-nilai karakter yang diharapkan.

\section{Fokus Penelitian}

1. Kurikulum 2013

Secara etimologis kurikulum merupakan terjemahan dari bahasa Inggeris yaitu curriculum, yang berarti rencana mata pelajaran. ${ }^{2}$ Dalam bahasa Latin disebut curriculae yang berarti jarak yang harus ditempuh seorang pelari ${ }^{3}$, atau disebut currere yang berarti lari cepat, maju cepat ${ }^{4}$. Dalam bahasa Arab disebut manhaj yang berarti jalan yang terang atau jalan yang dilalui manusia pada berbagai bidang kehidupannya ${ }^{5}$. Dalam bahasa Yunani menurut Maksudin berasal dari akar kata karasso yang berarti cetak biru, format dasar, sidik jari. ${ }^{6}$ Sedangkan menurut Musfiroh disebut To mark yang berarti menandai dan memfokuskan bagaimana mengaplikasikan nilai kebaikan itu dalam bentuk tindakan atau tingkah laku. ${ }^{7}$ Kemudian istilah itu digunakan untuk sejumlah mata pelajaran dalam kursus (courses of study) atau mata pelajaran yang harus ditempuh untuk mencapai suatu gelar atau ijazah". Kurikulum secara istilah berarti "sekumpulan materi pelajaran yang dihajatkan untuk lulus atau untuk guna mendapatkan ijazah dalam suatu bidang studi tertentu"9.

Secara nasional diberi patokan bahwa kurikulum adalah seperangkat rencana dan pengaturan mengenai tujuan, isi, dan bahan pelajaran serta cara yang digunakan sebagai pedoman penyelenggaraan kegiatan pembelajaran untuk mencapai tujuan pendidikan tertentu. ${ }^{10}$

Dapat ditegaskan bahwa kurikulum secara sempit adalah rancangan pengajaran yang isinya sejumlah mata pelajaran yang disusun secara sistimatis, berjenjang yang harus diselesaikan sebagai syarat untuk menyelesaikan suatu program, serta untuk mendapatkan bukti atau ijazah dari program tersebut. Sedangkan secara luas dapat dikatakan bahwa kurikulum adalah seperangkat rencana dan pengaturan dalam pendidikan dan pengajaran yang digunakan sebagai pedoman penyelenggaraan kegiatan belajar-mengajar.

\footnotetext{
${ }^{2}$ John M. Echols, dan Hassan Shadily, Kamus Inggeris Indonesia, (Jakarta: PT. Gramedia, 1984), 160.

${ }^{3}$ Oemar, Hamalik, Kurikulum dan Pembelajaran, (Jakarta: PT. Bumi Aksara, 1999), h. 16.

${ }^{4}$ Hasibuan, JJ. Developmen Supervision, (Alexandria: ASCSD, 1979), h.90.

${ }^{5}$ Husain ,Qurah, Al-Ushul al-Tarbiyah Fi Binai Al-Manhaj, (Mesir : Darul Ma’rif, 1975), h. 76.

${ }^{6}$ Maksudin, Pendidikan Karakter Non -Dikotomik, , (Yogyakarta: Pustaka Pelajar, 2013), h.1.

${ }^{7}$ Lihat Agus Wibowo, Pendidikan Karakter di Perguruan Tinggi, (Yogyakarta: Pustka Pelajar, 2013), h.36.

${ }^{8}$ Hamdani, Ihsan dan Fuad Ihsan, Filsafat Pendidikan Islam, (Bandung: CV. Pustaka Setia, 1998), h. 131

${ }^{9}$ Carter V. Good, Dictionary Of Education, (New York: Mc. Graw Hill Book Company, 1959), h. 113.

${ }^{10}$ Lihar Undang-Undang No. 20 Tahun 2003 tentang Sistim Pendidikan Nasional dan PP. Nomor 19
} Tahun 2005. 
Kurikulum 2013 dikembangkan berdasarkan standar pendidikan yang berbasis kompetensi, dengan menetapkan standar kualitas minimal hasil belajar yang berlaku setiap kurikulum. Standar nasional itu dinyatakan sebagai standar kompetensi lulusan yang mencakup sikap, pengetahuan dan ketrampilan.

\section{Pembelajaran PAI}

Pembelajaran pada dasarnya berasal dari kata ajar, yang artinya barang apa yang dikatakan kepada orang supaya diketahui atau dituruti. Dari akar kata tersebut muncul kata: mengajar, mengajari, mempelajari, pengajaran, pengajar dan pembelajaran. Belajar artinya berusaha supaya beroleh kepandaian/ilmu, atau proses dan usaha mencari pengalaman dan perubahan yang diingini ${ }^{11}$. Dirumuskan oleh Winkel bahwa belajar adalah suatu aktivitas mental/psikis, yang berlangsung dalam interaksi aktif dengan lingkungan yang menghasilkan perubahan-perubahan dalam pengetahuan-pemahaman, ketrampilan dan nilai sikap. Perubahan itu bersipat relatif konstan dan berbekas ${ }^{12}$. Oleh Syaiful Bahri Djamarah dijelaskan bahwa: belajar adalah serangkaian kegiatan jiwa raga untuk memperoleh suatu perubahan tingkah laku sebagai hasil dari pengalaman individu dalam interaksi dengan lingkungan yang menyangkut kognitif, afektif dan psikomotor. ${ }^{13}$ Sehingga belajar itu kelihatan ciri-cirinya. Adapun ciri-ciri kegiatan belajar : 1) ada suatu aktivitas yang menghasilkan perubahan, 2) perubahan itu berupa kemampuan baru, yang berlaku dalam waktu tertentu yang relatif lama, 3) perubahan itu terjadi karena ada usaha (keaktivan). Belajar adalah proses Individual: perubahan yang terjadi dalam diri pribadi yang bersangkutan melalui berbuat dan mengalami sendiri. Aktif: dalam arti yang bersangkutan harus serius, karena tidak mungkin terjadi perubahan kalau tidak disertai kemauan. Perubahan dalam bentuk: konwledge, achievement, skill, value, sikap, kebiasaan, kognitif, afektif. Dan sipat perubahan itu: intensional, positif, aktif, efektif dan fungsional.

Secara sederhana pembelajaran dimaksudkan adalah usaha mengelola lingkungan dengan sengaja, agar seseorang membentuk diri secara positif dalam kondisi tertentu, demikian halnya dalam UU.No.2 Tahun 2003 tentang Sisdiknas Pasal 1 ayat 20 disebutkan bahwa: "pembelajaran adalah proses interaksi peserta didik dengan pendidik dan sumber belajar pada suatu lingkungan belajar". ${ }^{14}$

Secara operasional dapat ditegaskan bahwa: Pembelajaran adalah hasil pengembangan dari pengajaran yang dilakukan oleh seorang guru untuk membelajarkan peserta didik, melalui berbagai cara, upaya, strategi, metode dan pendekatan untuk mencapai tujuan yang telah direncanakan. Dengan demikian hakekat pembelajaran adalah pelaksanaan dari kurikulum sekolah untuk

\footnotetext{
${ }^{11}$ WJS, Poerwadarminta, Kamus Umum Bahasa Indonesia, (Jakarta: Balai Pustaka, 1976) ,h. 108. ${ }^{12}$ WS, Winkel, Psikologi Pengajaran, (Jakarta: PT. Gramedia Widiasarana Indonesia, 1996), h. 53. ${ }^{13}$ Syaiful Bahri Jamarah, Psikologi Belajar, (Jakarta: PT. Rineka Cipta, 2002), h. 13.

${ }^{14}$ Indah Komisiyah, Belajar dan Pembelajaran, (Cet.I, Yogyakarta: Teras, 2021), h. 4.
} 
menyampaikan materi pelajaran kepada peserta didik, agar terjadi peristiwa belajar pada diri peserta didik.

Pembelajaran PAI di madrasah meliputi al-Qur'an Hadis, Akidah Akhlak, Fiqhi, Sejarah Kebudayaan Islam ${ }^{15}$ dan Bahasa Arab, sedangkan di sekolah pembelajaran PAI inclusive empat mata pelajaran tersebut.

Dengan lahirnya Undang-Undang nomor 2 tahun 1989 tentang SISDIKNAS, semakin memantapkan posisi PAI dalam sistem pendidikan nasional, karena di dalamnya dimuat tetang pendidikan agama yang wajib dimasukkan dalam kurikulum setiap jenis, jalur dan jenjang pendidikan. ${ }^{16}$ Bahkan dalam penyempurnaannya dalam Undang-Undang Sikdisnas nomor 20 tahun 2003 tetntang pelaksanaan pendidikan agama semakin mendapatkan perhatian dari pemerintah, sebagaimana pada Bab I (Ketentuan Umum) pasal 1 ayat (2) disebutkan bahwa:

Pendidikan nasional adalah pendidikan yang berdasarkan Pancasila dan Undang-Undang Dasar Negara Republik Indonesia Tahun 1945 yang berakar pada nilai-nilai agama, kebudayaan nasional Indonesia dan tanggap terhadap tuntutan perubahan zaman. ${ }^{17}$

Selanjutnya ketentuan mengenai pendidikan agama semakin dipertegas dengan lahirnya Peraturan pemerintah RI nomor 55 tahun 2007 tentang pendidikan agama dan pendidikan keagamaan yaitu pada Bab I (Ketentuan Umum) pasal 1 ayat 1 disebutkan bahwa;

Pendidikan agama adalah pendidikan yang memberikan pengetahuan dan membentuk sikap, kepribadian, dan keterampilan peserta didik dalam mengamalkan ajaran agamanya, yang dilaksanakan sekurang-kurangnya melalui mata pelajaran/kuliah pada semua jalur, jenjang dan jenis pendidikan. ${ }^{18}$

Kemudian selanjutnya keluar surat edaran Dirjen Pendidikan Islam Nomor: DJ.II.I/PP.00/ED/681/2006 tanggap 1 Agustus 2006, tentang pelaksanaan Standar isi, menyebutkan bahwa yang termasuk dalam materi PAI adalah: Qur'an Hadis, Aqidah Akhlak, Fiqih dan Sejarah Kebudayaan Islam. ${ }^{19}$ Keempat materi tersebut masing-masing memiliki ciri, fungsi dan tujuan, yang kesemuanya mengarah pada terbentuknya perilaku peserta didik sesuai tuntunan ajaran Islam.

Dapat ditegaskan bahwa pendidikan agama Islam merupakan sebutan yang diberikan pada salah satu subyek pelajaran yang harus dipelajari oleh siswa muslim dalam menyelesaikan pendidikannya pada tingkat tertentu, seperti pada Madrasah Islamiyah (MI) dan Madrasah Tsanawiyah (MTs) serta Madrasah Aliyah (MA).

${ }^{15}$ Permenag Nomor 000912 Tahun 2013 dan Lihat Muhaimin, Sutiah, Sugeng Listyo Prabowo, Pengembangan Model Kurikulum Tingkat Satuan Pendidikan (KTSP) pada Sekolah dan Madrasah, (Jakarta: Rajawali Pers, 2009), h. 52-56.

${ }^{16}$ Redaksi Sinar Grafika, Edisi Tahun 1995 (Cet.I, Jakarta: Sinar Grafika, 1995), h. 16.

${ }^{17}$ Redaksi Sinar Grafika, Edisi Tahun 1995 (Cet.I, Jakarta: Sinar Grafika, 1995), h. 3.

18 Weinata Sairin, Himpunan Peraturan di Bidang Pendidikan, (Cet.I, Jakarta: Jala Permata Aksara, 2010), h. 226.

19 Muhaimi, Sutiah Sugeng Listyo Prabowo, Pengembangan Model Kurikulum Tingkat Satuan Pendidikan (KTSP) pada Sekolah \& Madrasah, (Edisi.I, Cet. II, Jakarta : Rajawali Pers, 2009), h. 52-56. 


\section{Karakter}

Menurut Dani Setiawan karakter berasal dari bahasa Latin yaitu

kharakter, kharassein dan kharax yang bermakna tools for marking, to engrave dan pointed stake, dalam bahasa Perancis caractere, kemudian masuk ke dalam bahasa Inggeris berubah menjadi character, yang dalam bahasa Indonesia disebut karakter. ${ }^{20}$ Dalam bahasa Indonesia karakter sama artinya dengan tabiat, watak, sipat-sipat kejiwaan dan akhlak atau budi pekerti yang membedakan seseorang daripada yang lain. ${ }^{21}$ Musfiroh mengemukakan bahwa karakter berasal dari bahasa Yunani yang berarti to mark: menandai dan memfokuskan bagaimana mengaplikasikan nilai kebaikan itu dalam bentuk tindakan atau tingkah laku. Kemudian secara istilah karakter didefinisikan sebagai kualitas-kualitas yang teguh dan khusus yang dibangun dalam kehidupan seorang yang menentukan responnya tanpa pengaruh kondisi-kondisi yang ada. ${ }^{22}$ Secara operasional dapat ditegaskan bahwa: Karakter adalah aplikasi dari nilai-nilai kebaikan dalam bentuk tindakan atau tingkah laku maupun cara berpikir yang menjadi ciri khas individu dalam kehidupannya, baik dalam kehidupan keluarga, rumah tangga, masyarakat pada umumnya maupun terhadap bangsa dan negara.

\section{A. Tujuan Pendidikan Karakter Menurut Kurikulum 2013 dan Tujuan Pembelajaran PAI}

Tujuan merupakan komponen yang sangat penting dalam setiap proses pembelajaran karena menjadi acuan seluruh langkah-langkah dalam proses tersebut. Di samping itu juga menjadi tolok ukur keberhasilan proses pembelajaran. Tujuan merupakan gambaran tentang perilaku yang diharapkan tercapai oleh peserta didik setelah mengikuti proses tersebut. Perilaku yang diharapkan secara operasional digambarkan dalam bentuk karakteristik sosok individu yang diidealkan untuk bisa terwujud dalam diri peserta didik setelah proses pendidikan selesai.

Karakter dinilai menurut hubungan manusia dengan tuhan, diri sendiri, sesama dan lingkungan, bangsa dann Negara. Sedangkan hubungan manusia dengan Tuhan dinilai menurut derajat taqwa dan sikap relegius. Hubungan manusia dengan diri sendiri dinilai berdasarkan sikap jujur, tanggung jawab, gaya hidup sehat, disiplin, kerja keras, percaya diri, berjiwa wirausaha, kreatif, inovatif, mandiri dan mempunyai rasa ingin tahu. Sementara hubungan manusia dengan sesama dinilai berdasarkan sikap sadar hak dan kewajinan, patuh pada aturan sosial, menghargai karya orang lain, santun dan demokratis, peduli lingkungan sosial dan lingkungan hidup. Sedangkan hubungan manusia dengan Bangsa dan Negara dinilai berdasarkan sikap nasionalisme, menghargai keberagaman dan memahami budaya dan ekonomi.

${ }^{20}$ Lihat Agus Wibowo, Pendidikan Karakter di Perguruan Tinggi, (Yogyakarta: Pustaka Pelajar, 2013), h.33-34.

${ }^{21}$ Poerwadarminta, WJS. Kamus Umum Bahaasa Indonesia, (Jakarta: PN Balai Pustaka, 1976), h. 445 .

${ }^{22}$ Agus Wibowo, Pendidikan Karakter di Perguruan Tinggi, (Yogyakarta: Pustaka Pelajar, 2013), h.34. 
Pendidikan karakter harus masuk dalam setiap kegiatan belajar-menajar di ruang kelas, praktek keseharian di sekolah dan terintegrasi dengan setiap kegiatan ekstrakurikuler seperti pramuka, pencinta alam, palang merah, olah raga dan karya tulis ilmiah. Setelah itu setiap siswa diharapkan mampu menerapkan di rumah dan lingkungan sekitarnya secara berkesinambungan.

Di Madrasah Tsanawiyah Watampone diselenggarakan pendidikan secara sistimatis dalam rangka pembentukan karakter peserta didik, agar mampu bersaing, beretika, bermoral, sopan santun dan berinteraksi dengan masyarakat dan lingkungan sekitar, sehingga mampu menghadapi persoalan dan tantangan hidupnya.

Pendidikan karakter memiliki makna lebih tinggi dari pendidikan moral, karena pendidikan karakter tidak hanya berkaitan dengan masalah benar-salah, tetapi bagaimana menanamkan kebiasaan tentang hal-hal baik dalam kehidupn secara kuat, mendarah daging, agar anak memiliki kesadaran, pemahaman kepedulian dan komitmen untuk menerapkan kebajikan dalam kehidupan sehari-hari.

Pendidikan agama Islam diintegrasikan dengan pendidikan karakter untuk mengoptimalkan perkembangan seluruh dimensi paerta didik (kognitif, fisik, sosial, emosi, kreaivitas dan spritual) sebagai upaya pembentukan manusia yang utuh, sehingga unggul dalam karakter serta mampu menghadapi tantangan hidupnya.

Akmal Hawi berpendapat bahwa pendidikan Agama Islam adalah usaha sadar dan terencana dalam menyiapkan peserta didik dalam meyakini, memahami, menghayati, dan mengamalkan agama Islam melalui kegiatan bimbingan, pengarahan atau latihan, dengan memperhatikan tuntutan untuk menghormati agama lain dengan hubungan antara umat beragama dalam masyarakat untuk mewujudkan kesatuan nasional. ${ }^{23}$ Dari pendapat tersebut dapat dipahami bahwa pembelajaran PAI merupakan usaha untuk membekali peserta didik, agar memiliki perilaku agama dan bermental terpuji, sehingga dapat menjadi teladan dan berakhlak mulia dalam kehidupan sehari-hari.

Pendidikan agama Islam sebagai salah satu bidang studi yang dipelajari pada satuan pendidikan, mulai dari tingkat sekolah dasar sampai perguruan tinggi, sengaja diselenggarakan dengan hasrat atau niat untuk lebih memperdalam pengetahuan dalam mengamalkan ajaran dan nilai-nilai Islam. Sebagaimana tujuan pendidikan agama Islam yaitu mengarahkan perkembangan kepribadian (psiko-pisik) manusia sesuai hakekatnya, agar menjadi manusia pripurna (insan kamil) dalam rangka mencapai tujuan akhir kehidupannya, yaitu kebahagiaan hidup di dunia dan di akhirat. $^{24}$

${ }^{23}$ Akmal Hawi, Kompetensi Guru Pendidikan Agama Islam, (Cet.I, Jakarta: Rajawali Pers, 2003), h. 25.

${ }^{24}$ M. Arifin, Ilmu Pendidikan Islam Suatu Tinjauan Teoritis dan Praktis Berdasarkan Pendekatan Interdisipliner, (Cet.I, Jakarta: Bumi Aksara, 1993), h. 40. 
PAI adalah mata pelajaran yang penting dan harus diterapkan dalam setiap jenjang pendidikan, karena tidak hanya mengajarkan pengetahuan tentang agama Islam, tetapi terkait upaya mengarahkan peserta didik, agar menghiasi diri dan memiliki kualitas iman, taqwa dan akhlak mulia dalam kepribadiannya di manapun mereka berada dan dalam posisi apapun kerjaan mereka.

Begitu pentingnya peran PAI dalam proses pendidikan dewasa ini, sehingga pembelajaran PAI harus mendapatkan perhatian lebih, terutama dalam mengembangkan moral peserta didik, karena PAI menyentuh keseluruhan ranah pendidikan. Terkait dengan itu M. Athiyah Al-Abrasyi menekankan bahwa:"pembentukan moral yang tinggi adalah tujuan utama dalam pendidikan Islam". 25

Pembelajaran PAI di MTsN Watampone telah terlaksana berdasarkan struktur kurikulum yang dikelola oleh Kementerian Agama RI, yang sarat dengan nilai-nilai karakter, dan sesuai dengan kebijakan pemerintah dalam menerapkan kurikulum 2013.

Adapun materi PAI yang dikembangkan dalam satuan pendidikan adalah :

1. Al-Qur'an-Hadis, bertujuan untuk memberikan kemampuan dasar kepada peserta didik dalam membaca, menulis, menggemari al-Qur'an dan hadis serta penghayatannya.

2. Aqidah Akhlak, bertujuan untuk menumbuhkan dan meningkatkan keimanan peserta didik yang diwujudkan dalam akhlak terpuji.

3. Fiqh yaitu untuk membekali peserta didik agar dapat mengetahui dan memahami pokokpokok hukum Islam secara terperinci dan menyeluruh, serta mengamalkan ketentuan hukum Islam yang benar.

4. Sejarah Kebudayaan Islam, yaitu bertujuan untuk membekali peserta didik dengan pengetahuan tentang sejarah dan kebudayaan Islam, mengambil makna dan nilai serta menanamkan penghayatan yang terdapat dalam sejarah. ${ }^{26}$

Dapat ditegaskan bahwa tujuan pendidikan agama disekolah/madrasah adalah menumbuhkan dan meningkatkan keimanan melalui pemberian dan pemupukan pengetahuan, pengalaman, penghayatan, dan pengamalan dari peserta didik tentang agama Islam, sehingga menjadi manusia muslim yang terus berkembang dalam keimanan dan ketaqwaannya dalam beragama, berbangsa dan bernegara, serta untuk dapat melanjutkan pada pendidikan yang lebih tinggi, hingga terbentuknya kepribadian yang mencerminkan ajaran-ajaran agama Islam dan bertaqwa kepada Allah demi terbentuknya manusia paripurna (Insan kamil).

\section{B. Aplikasi Metode dalam Menanamkan Niai-Nilai Karakter pada Peserta Didik di MTsN Watampone}

Penerapan Metode dalam Pembelajaran PAI Sebagai Upaya Menanamkan nilai-nilai karakter pada peserta didik di MTsN Watampone.

1. Metode Scientific. ${ }^{27}$

${ }^{25}$ M. Athiyah Al-Abrasyi, Manajemen Pendidikan Pesantren, (Jakarta: Traswacana, 2008), h. 38.

${ }^{26}$ Khaeruddin. dkk, Kurikulum Tingkat Satuan Pendidikan (KTSP) Konsep dan Impelementasinya di Madrasah, (Cet.I, Yogyakarta: Pilar Media, 2007), h. 178-179.

${ }^{27}$ Metode scientific dapat dilihat, Ramayulis, Metodologi Pendidikan Agama Islam, (Ce. 4, Jakarta: Kalam Mulia, 2005), h, 151-213. Demikian juga Wina Sanjaya, Strategi Pembelajaran Berorientasi Standar Proses Pendidikan,, (Cet.5, Jakarta: Kencana Media Group, 2008), h. 193-288. Dan Mel Siberman, Active 
Proses Pembelajaran Kurikulum 2013 menggunakan metode saintifik yang dikenal 5 M. yaitu: mengamati, menanya, mengumpul, menalar dan mengomunikasikan. Diaplikasikan lewat metode scientific, seperti: Contekstual Teaching Learning. Enqueri, Problem Solving, Komunikatif, Kooperatif dan sebagainya. Dan selalu bertolak dan berpedoman pada kurikulum inti, yang dikenal empat KI yaitu: KI. 1: Sikap Spiritual KI.2: Sikap Sosial, KI. 3: Pengetahuan, dan KI.4: Ketrampilan.

Upaya guru dalam memilih metode yang baik merupakan upaya mempertinggi mutu pengajaran atau pendidikan yang menjadi tanggung jawabnya. Dengan demikian pembentukan karakter siswa sangat ditentukan oleh profesional guru dan kecerdasan emosionalnya, melalui penguasaan metodologi, sebagai bekal untuk mentranfer pengetahuan, kecakapan, internalisasi nilai-nilai sesuai mata pelajaran yang dibinanya secara efektif dan efsien.

Pembelajaran PAI dapat dilakukan dengan berbagai metode, baik dengan metode scientific, maupun dengan pembelajaran cara umum atau konvensional diterapkan dalam kelas atau di luar kelas, seperti : metode ceramah, tanya jawab, demostrasi, eksperimen, diskusi, sosio drama dan bermain peran, mengajar beregu, pemecahan masalah, pemberian tugas (resitasi), kerja kelompok, simulasi, studi kemasyarakatan (karyawisata dan survey) dan sebagainya. ${ }^{28}$ Semua metode memiliki kelebihan dan kekurangan, oleh karena itu seorang guru PAI harus berusaha meminimalisir kelemahan dengan menggunakan metode lain sebagai pelengkap, karena tidak ada suatu metode yang mapan dan cocok untuk semua mata pelajaran dalam lingkup pembelajaran PAI. Kehadiran metode scientific akan memperkaya metode umum yang telah mewarnai metode pembelajaran PAI sebelumnya. Antara metode scientific dan metode konvensional dalam pembelajaran PAI saling mendukung, namun metode scientific sifatnya lebih melengkapi dan lebih memperkaya dalam menanamkan karakter terhadap peserta didik, karena dengan metode scientific peserta didik berusaha memahami, mencari, menggali dan membuktikan sendiri tentang suatu materi pendidikan karakter.

\section{Materi Penanaman Karakter di MTsN Watampone.}

Penananaman nilai karakter mengacu pada kurikulum 2013 yang telah ditetapkan oleh Kemendiknas No. 68 Tahun 2013 untuk SMP/MTs, yaitu: Beriman, jujur, disiplin, tanggung jawab, peduli, (toleransi, gotong royong), santun, percaya diri dalam beinteraksi secara efektif dengan lingkungan sosial dan alam dalam jangkaun pergaulan dan keberadaannya. Sebelumnya guru di MTsN Watampone telah berusaha menanamkan karakter terhadap peserta didik berbasis Rabbani, seperti cara Lukman al-Hakim dalam mendidik anak-anaknya, sesuai maksud dalam al-Qur'an

Learning 101 Strategi Pembelajaran Aktif, (Cet.2, Yogyakarta: Yapendis, 2001), h. 68-281. Serta Hisyam Zaini, Barmawy Munthe, Sekar Ayu Aryani, Strategi Pembelajaran Aktif, (Cet. 6, Yogyakarta: Center for Teaching Staff Development (CTSD) IAIN Sunan Kalijaga, 2007), h. 8-129.

${ }^{28}$ Ramayulis, Metodologi Pendidikan Agama Islam, (Cet.4, Jakarta: Kalam Mulia, 2005), h. 215319.Dapat juga dilihat Chabib Toha, Saifuddin Zuhri, Syamsuddin Yahya, Metodologi Pengajaran Agama, (Cet.II, Yogyakarta: Pustaka Pelajar, 2004), h. 95. 
Surah (31) Lukman, ayat ke 13-19. Yaitu: penanaman aqidah, menyadari diri dalam keadaan diawasi oleh Allah swt, menegakkan salat, banyak bersabar, melakukan apa yang diperintahkan dan menghindari apa yang dilarang agama, berpola hidup sederhana dan tidak sombong (angkuh). Karakter tersebut telah ditanamkan cukup intens, tinggi, positif dan membudaya, karena tujuannya sama yaitu membentuk akhlak terpuji dan terhindar dari akhlak tercelah

Penanaman karakter telah dilakukan sebelum dijabarkannya kurikulum 2013, namun perkembangannya sangat pesat tiga tahun terakhir, yaitu sejak tahun 2016-2019 setelah dijabarkan kurikulum 2013 dengan menerapkan strategi pembinaan Osis, Pramuka, PMR. PKS, SSB, Drumband, Rohis, Kir, Pesantren Kilat dan Group Olahraga.

\section{Profesinalisme Guru PAI Sebagai Kemampuan Dasar Dalam Menanamkan Nilai-Nilai Karakter di MTsN Watampone}

Guru PAI menjadi tulang punggung, sekaligus faktor kunci penanaman karakter di MTsN Watampone, oleh karena itu guru PAI memegang peran penting dan sangat menentukan berhasil tidaknya penanaman karakter bagi siswa. Nilai sorang guru PAI adalah menjadi pewaris para Nabi, sehingga Guru PAI sebagai penyalur hikmah dan berkah dari Allah swt, kepada peseta didiknya, agar dapat mengenal dan bertaqwa kepada Allah swt, dan mengenal fitrahnya. Sudah menjadi sunnatullah bahwa tugas utama guru PAI adalah menanamkan nilai-nilai karakter secara permanen dengan melihat prioritas yang cocok dari setiap mata pelajaran dan setiap pokok bahasan, sehingga tidak ada nilai-nilai karakter yang terlupakan sesuai tingkatan.

Dapat ditegaskan bahwa tugas guru PAI ialah mendidik peserta didiknyadalam berbagai hal demi tercapainya perkembangan peserta didik secara maksimal sesuai nilai-nilai ajaran Islam. Dari situ dapat dilihat dan dipahami bahwa harapan akan berhasilnya penerapan kurikulum 2013 dan pembelajaran PAI dalam menanamkan karakter adalah sangat tergantung pada kemampuan dan keperibadian guru. Dengan demikian kedudukan guru memiliki posisi sentral dalam membentuk karakter atau keperibadian peserta didik. Keteladanannya sangat berpengaruh pada lingkungan sekitarnya, bahkan dapat memberi warna yang cukup besar pada masyarakat lingkungan sekitarnya, karena dengan keteladanannya mampu mengubah perilaku siswa dalam lingkungan kerjanya dan mengubah masyarakat di lingkungan tempat tinggalnya. Dengan begitu, maka guru PAI adalah sosok yang diharapkan menjadi pengubah tingkah laku dan pola pikir siswa dan masyarakat menuju pribadi yang lebih baik.

Pendidikan Agama Islam (PAI) diartikan sebagai suatu kegiatan yang berujuan untuk membentuk manusia agamis dengan menanamkan akidah keimanan, amaliah dan budi pekerti atau akhlak yang terpuji untuk menjadi manusia yang taqwa kepada Allah swt. ${ }^{29}$ h. 4 .

\footnotetext{
${ }^{29}$ Basyiruddin Usman, Metodologi Pembelajaran Agama Islam, (Cet. I, Jakarta: Ciputat Press, 2002),
} 
Guru dewasa ini harus mengikuti perkembangan ilmu pengetahuan dan teknologi yang mutakhir, agar memiliki wawasan yang luas dan tidak tertinggal dengan informasi terkini. Guru harus mempunyai visi kedepan dan siap menghadapi perubahan zaman yang tidak menentu, sehingga membutuhkan kecakapan dan kesiapan yang baik dan siap bergeser dari pola pikir tradisional menuju pola pikir yang professional. Keberhasilan guru PAI dalam tugasnya, tidak hanya terletak pada penyampaian materi secara tuntas dengan metode yang berbasis scientific berdasarkan kompetensi inti (KI) dan kompetensi dasar (KD) di depan kelas, ataupun dengan cara konvensional di depan kelas, tetapi hendaknya guru PAI berbeda dengan guru pada umumnya, dalam artian harus mempunyai karakteristik tersendiri dengan menyandang akhlakul karimah dalam kepribadiannya, sehingga dengan kepribadian itu teraktualisasi lewat perkataan dan perbuatannya, yang mencerminkan watak dan sifat rabbani, mencari keredaan Allah, menggunakan metode pembelajaran secara bervariasi, sabar, adil dan jujur dalam kesehariannya.

\section{Impelementasi Pembelajaran PAI dalam Menanamkan Nilai-nilai Karakter di MTsN}

\section{Watampone}

Mengajar yang berkarakter caranya adalah mengajak, merangkul, menarik, mengundang, mengangkat dan menyayangi. Disamping itu perlu diingat bahwa mengajar yang berkualitas perlu: persiapan mantap, mengkomunikasikan tujuan, menyajikan materi esensial, penyajian yang multi: metode, aproach, teknik media, strategi, interaksi yang humanis, kontak yang berkesinambungan, hiden kurikulum terlaksana, semua tipe peserta didik terlayani, melakukan evaluasi formatif dan balikan, pemanfaatan waktu yang wajar dan sesuai.

Impelementasi pembelajaran PAI dalam menanamkan nilai-nilai karakter peserta didik di MTsN Watampone, adalah lebih mengandalkan kepribadian dan keteladanan guru. Seorang pendidik harus memilih pendekatan yang cocok dengan karakter peserta didiknya, agar peserta didik merasa nyaman dan bergairah mengikuti pelajaran.

Guru PAI yang orientasi pengajarannya berusaha menanamkan nilai-nilai karakter pada peserta didik, melalui keteladanan, agar menjadi manusia yang selalu menyandang akhlakul karimah. Kondisi seperti itu, menunjukkan bahwa karakter siswa MTsN Watampone, terbentuk dan dipengaruhi oleh kemampuan dan keteladanan yang dimiliki oleh guru.

Suatu profesi dituntut adanya keahlian dan etika khusus serta standar layanan termasuk profesi sebagai guru. Dengan kata lain profesi guru bukan pekerjaan yang dilakukan oleh mereka, yang karena tidak memperoleh pekerjaan lain tetapi dilakoni oleh orang yang memiliki kualifikasi profesional.

Profesional guru bukan hanya dinilai dari kualifikasi akademiknya saja akan tetapi guru juga diharapkan memiliki kemampuan dan keterampilan dasar mengajar, agar guru dapat melaksanakan perannya dalam proses pembelajaran, sehingga pembelajaran berjalan efektif dan efesien. 


\section{SIMPULAN DAN SARAN}

Secara konsepsional kurikulum 2013 sangat mengandalkan metode Scinetifik yang dalam penerapannya lebih popular dengan istilah lima $5 \mathrm{M}$ yaitu: mengamati, menanya, mengumpul, menalar dan mengomunikasikan, dan diaplikasikan lewat metode dan pendekatan scientific, seperti: Contekstual Teaching Learning. Enqueri, Problem Solving, Komunikatif, Kooperatif dan sebagainya. Dan selalu bertolak dan berpedoman pada kurikulum inti, yang dikenal empat KI yaitu: KI. 1: Sikap Spiritual KI.2: Sikap Sosial, KI. 3: Pengetahuan, dan KI.4: Ketrampilan. 2) Impelementasi penananaman nilai karakter mengacu pada kurikulum 2013 yang telah ditetapkan oleh Kemendiknas No 68 Tahun 2013 untuk SMP/MTs, yaitu: Beriman, jujur, disiplin, tanggung jawab, peduli, (toleransi, gotong royong), santun, percaya diri dalam beinteraksi secara efektif dengan lingkungan sosial dan alam dalam jangkaun pergaulan dan keberadaannya. Karakter tersebut telah ditanamkan secara terintegrasi dengan pembelajaran PAI, oleh guru PAI yang cukup profesional, sehingga hasilnya cukup intens, tinggi, positif dan membudaya, dalam upaya membentuk akhlak terpuji dan terhindar dari akhlak tercelah. Ditanamkan oleh guru pada umumnya dan guru PAI pada khususnya sebagai sosok yang profesional menjadi pengubah tingkah laku dan pola pikir peserta didiknya menuju pribadi yang lebih baik. Tujuan kurikulum 2013 sangat relevan dengan pembelajaran PAI, sehingga dalam impelementasinya senada dan setujuan dalam membentuk sikap mental spiritual, sikap sosial, pengetahuan dan keterampilan. Artinya manusia yang akan dibentuk adalah manusia yang bermental atau bermoral, intelektual dan punya skill, atau yang akan dibentuk adalah hatinya (aspek afektif), kepalanya (aspek kognitif) dan tangan atau kaki (aspek psiko mtorik). Agar peserta didik memiliki akhlak terpuji (akhlak mahbubah) dan terhindari dari akhlak tercelah (akhlak mazmumah). Atau dengan kata lain bahwa manusia yang menjadi sasaran adalah manusia yang mampu menjalankan perintah (amar ma'ruf) dan mencegah diri dari perbuatan yang diralaran/tercelah (nahi munkar), sehingga terpelihara secara harmonis hubungan dengan Allah swt (hablun minallahi) dan hubungan sesama manusia (hablun minannasi).

Adapun implikasi hasil penelitian bahwa 1) konsep pendidikan karakter menurut kurikulum 2013 sangatlah islamy, oleh karena itu hendaknya menjadi perhatian bagi semua guru, orang tua dan pemerintah dalam mewujudkan karakter yang baik itu sebagai ending dari keimanan dan keislaman peserta didik. 2) Impelementasi penanaman dan pembentukan karakter terhadap anak (peserta didik) diharapkan dilakukan secara terpadu antara rumah tangga, sekolah dan masyarakat. Dan dilakukan secara berjenjang dan berkelanjutan demi terwujudnya kepribadian yang luhur.

\section{DAFTAR RUJUKAN}

Al-Abrasyi, M. Athiyah. Manajemen Pendidikan Pesantren, Jakarta: Traswacana, 2008.

Alexander, Saylor \& Lewis. Curriculum Planning For Better Teaching and Learning, HoltRinehart 
and Winston, 1981.

Arifin, M. Ilmu Pendidikan Islam Suatu Tinjauan Teoritis dan Praktis Berdasarkan Pendekatan Interdisipliner, Cet.I, Jakarta: Bumi Aksara, 1993.

Echols, John M. dan Hassan Shadily, Kamus Inggeris Indonesia, Jakarta: PT. Gramedia, 1984.

Good, Carter V. Dictionary Of Education, New York: Mc. Graw Hill Book Company, 1959.

Hamalik, Oemar. Kurikulum dan Pembelajaran, Jakarta: PT. Bumi Aksara, 1999.

Hasibuan, JJ. Developmen Supervision, Alexandria: ASCSD, 1979.

Hawi, Akmal. Kompetensi Guru Pendidikan Agama Islam, Cet.I, Jakarta: Rajawali Pers, 2003.

Ihsan, Hamdani. dan Fuad Ihsan. Filsafat Pendidikan Islam, Bandung: CV. Pustaka Setia, 1998.

Jamarah, Syaiful Bahri. Psikologi Belajar, Jakarta: PT. Rineka Cipta, 2002.

Khaeruddin. dkk, Kurikulum Tingkat Satuan Pendidikan (KTSP) Konsep dan Impelementasinya di Madrasah, Cet.I, Yogyakarta: Pilar Media, 2007.

Komisiyah, Indah. Belajar dan Pembelajaran, Cet.I, Yogyakarta: Teras, 2021.

Maksudin, Pendidikan Karakter Non-Dikotomik, Yogyakarta: Pustaka Pelajar, 2013.

Permenag Nomor 000912 Tahun 2013.

PP. Nomor 19 Tahun 2005.

Poerwadarminta, WJS. Kamus Umum Bahasa Indonesia, Jakarta: Balai Pustaka, 1976.

Qurah, Husain. Al-Ushul al-Tarbiyah Fi Binai Al-Manhaj, Mesir : Darul Ma'rif, 1975.

Ramayulis, Ilmu Pendidkan Islam Cet. 4, Jakarta: Kalam Mulia, 2005.

Redaksi Sinar Grafika, Edisi Tahun 1995, Cet.I, Jakarta: Sinar Grafika, 1995.

Sairin, Weinata. Himpunan Peraturan di Bidang Pendidikan, Cet.I, Jakarta: Jala Permata Aksara, 2010

Sanjaya, Wina. Kurikulum dan Pembelajaran, Jakarta: Kencana, 2008.

-------, Wina. Strategi Pembelajaran Berorientasi Standar Proses Pendidikan, Cet.5, Jakarta:

Kencana

Media Group, 2008.

Siberman, Mel. Active Learning 101 Strategi Pembelajaran Aktif, Cet.2, Yogyakarta: Yapendis, 2001.

Sutiah, Muhaimin. Sugeng Listyo Prabowo. Pengembangan Model Kurikulum Tingkat Satuan Pendidikan (KTSP) pada Sekolah dan Madrasah, Jakarta: Rajawali Pers, 2009.

Toha, Chabib. Saifuddin Zuhri. Syamsuddin Yahya. Metodologi Pengajaran Agama, Cet.II, Yogyakarta: Pustaka Pelajar, 2004.

Undang-Undang No. 20 Tahun 2003 tentang Sistim Pendidikan Nasional

Usman, Basyiruddin. Metodologi Pembelajaran Agama Islam, Cet. I, Jakarta: Ciputat Press, 2002.

Wibowo, Agus. Pendidikan Karakter di Perguruan Tinggi, Yogyakarta: Pustka Pelajar, 2013.

Winkel, WS. Psikologi Pengajaran, Jakarta: PT. Gramedia Widiasarana Indonesia, 1996. 